\title{
OCCURRENCE OF FILARID PARASITES IN HOUSEHOLD AND SHELTERED DOGS IN THE CITY OF JOINVILLE - SANTA CATARINA, BRAZIL
}

\author{
OCORRÊNCIA DE FILARÍDEOS PARASITOS EM CÃES DOMICILIADOS E \\ PROVENIENTES DE ABRIGO ANIMAL DE JOINVILLE - SANTA CATARINA, \\ BRASIL
}

\author{
Anna Karina Kannenberg ${ }^{1}$ ORCID http://orcid.org/0000-0001-6501-2369 \\ Luca Frondana ${ }^{1}$ ORCID http://orcid.org/0000-0003-4468-1648 \\ Igor Henrique Rodrigues Martins ${ }^{1}$ ORCID http://orcid.org/0000-0003-1355-3686 \\ Charlene Edianez Longhi ${ }^{1}$ ORCID http://orcid.org/0000-0003-4515-2756 \\ Michele Müller Fialkowski ORCID http://orcid.org/0000-0001-9067-169X \\ Viviane Milczewski ${ }^{*}$ ORCID http://orcid.org/0000-0002-7117-5380 \\ ${ }^{1}$ Federal Institute of Santa Catarina, Araquari, SC, Brazil. \\ ${ }^{2}$ Badanievet Laboratory, Araquari, SC, Brazil. \\ “Corresponding author - viviane.milczewski@ifc.edu.br
}

\begin{abstract}
Parasites from the Filariidae family are among the nematodes that can infest dogs. Some may be apathogenic, such as Acanthocheilonema reconditum, and others such as Dirofilaria immitis are potentially zoonotic and may lead dogs to death. Thus, the aim of this study was to perform a survey on filarid infection in dogs with a fixed domicile and wandering dogs temporarily sheltered in the city of Joinville, SC, Brazil. Blood samples from 429 animals were collected from 2015 to 2017 and submitted to screening for microfilariae and/or D. immitis antigens. Our results revealed that twentyfour samples $(5.6 \%)$ displayed $A$. reconditum microfilariae and three samples $(0.7 \%)$ were positive for $D$. immitis, totaling 27 (6.3\%) positive animals for filarid parasites. Additionally, A. reconditum was more prevalent in dogs from shelters, whereas the three $D$. immitis positive samples were from household dogs that displayed no clinical signs of the presence of parasites. The occurrence of these parasites in dogs from Joinville indicates the importance of differential diagnosis of microfilaria species for the correct clinical management of infected dogs. Our epidemiological information may help the medical and veterinary community of the region regarding clinical suspicion of canine and human heartworm disease, as well as guide preventive actions targeting public and animal health.
\end{abstract}

Keywords: Acanthocheilonema reconditum, Dirofilaria immitis, microfilariae, zoonosis.

\section{Resumo}

Dentre os diversos nematódeos filarídeos que parasitam cães, alguns podem ser apatogênicos como Acanthocheilonema reconditum e outros como Dirofilaria immitis podem levar esses animais a óbito, além de terem potencial zoonótico. Nesse sentido, o objetivo deste trabalho foi realizar um 
levantamento da ocorrência de filarídeos em cães residentes em domicílio fixo e cães errantes que estavam temporariamente em um abrigo animal de Joinville-SC. Entre 2015 e 2017, amostras de sangue de 429 animais foram submetidas à busca de microfilárias ou antígenos de D. immitis, utilizando-se Método de Knott modificado e kit comercial de diagnóstico clínico. Vinte e quatro amostras $(5,6 \%)$ apresentaram microfilárias de $A$. reconditum e três $(0,7 \%)$ foram positivas para $D$. immitis, totalizando $27(6,3 \%)$ cães positivos para a presença de filarídeos parasitos. A. reconditum teve maior ocorrência em cães provenientes de abrigos, já os três cães positivos para $D$. immitis eram domiciliados e não apresentavam suspeita clínica de dirofilariose. A presença desses parasitos em cães da região denota a importância do diagnóstico diferencial das espécies de microfilárias para o encaminhamento clínico adequado dos cães parasitados. As informações epidemiológicas obtidas podem orientar a comunidade médica e veterinária em relação à atenção para as suspeitas clínicas de dirofilariose canina e humana, assim como na orientação das medidas de prevenção visando a saúde pública e animal.

Palavras-chave: Acanthocheilonema reconditum, Dirofilaria immitis, microfilárias, zoonose.

Received on June 15, 2018

Accepted on April 25, 2019

\section{Introduction}

Filarids (Filarioidea superfamily) are nematode parasites that are located in different organs of the definitive host and present a biological cycle characterized by the release of microfilariae in the circulation, which are ingested and transmitted by a hematophagous intermediate host.

In Brazil, several genera of filarids have been reported in domestic and wild mammals. Moraes et al. ${ }^{(1)}$ found Acanthocheilonema reconditum, Brugia sp., Dirofilaria immitis, Dirofilaria (Nochtiella) repens, and Mansonella sp. in coatis (Nasua nasua) in a preservation area of the Atlantic forest in Foz do Iguaçu, Paraná.

In the canine species, there has always been great interest in the identification of filarid parasites due to clinical relevance or possible zoonotic potential. Several filariae of domestic dogs have been reported around the world, such as Brugia pahangi( ${ }^{(2)}$, Dirofilaria (Nochtiella) repens ${ }^{(3)}$, Dipetalonema dracunculoides $^{(4)}$, Brugia malayi ${ }^{(5)}$, and Cercopithifilaria bainae ${ }^{(6)}$. The latter was recently reported in dogs in the Northeast region of Brazil ${ }^{(7)}$.

As in other regions of the world, Dirofilaria immitis and Acanthocheilonema reconditum are the most prevalent filarids in Brazil ${ }^{(7-10)}$. Filariae of Acanthocheilonema sp. are transmitted biologically by fleas (Ctenocephalides canis, Ctenocephalides felis, Pulex irritans, P. simulans, and Echidnophaga gallinae) or hematophagous lice (Heterodoxus spiniger and Linognathus setosus) during bloodsucking ${ }^{(11)}$. They are considered poorly pathogenic probably because they preferentially parasitize the subcutaneous tissue ${ }^{(12)}$. On the other hand, D. immitis is transmitted by several mosquitoes, such as Aedes vexans (Meigen), Anopheles quadrimaculatus (Say), Anopheles punctipennis (Say), Culex pipiens quinquefasciatus (Say), Culex erraticus (Dyer and Knab), Culiseta inornata (Williston), Psorophora columbiae (Dyer and Knab), Psorophora ferox (Humboldt), and Psorophora howardii

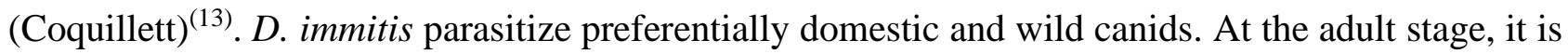


installed in the pulmonary artery and right ventricle and may cause signs of apathy, exercise intolerance, circulatory disorders such as vena cava syndrome or death.

Brazil presents a wide variation in the prevalence of heartworm disease among its different regions ${ }^{(10)}$. According to Labarthe and Guerrero ${ }^{(14)}$, coastal regions have a higher occurrence of heartworm disease due to the reproductive cycles of vector mosquitoes. The city of Joinville, located in northern Santa Catarina, bordered by the Babitonga Bay, and counting with $36 \mathrm{~km}^{2}$ of mangrove area, has climatic characteristics propitious for the spread of vectors ${ }^{(15)}$. It presents mean monthly precipitation of $183.6 \mathrm{~mm}^{(16)}$ and annual means of temperature and humidity of $22.4{ }^{\circ} \mathrm{C}$ and $80.76 \%$, respectively ${ }^{(17)}$.

Although Bublitz et al. ${ }^{(18)}$ have reported eight cases of human heartworm disease in Joinville, there are no studies that indicate the prevalence of dogs parasitized by filariae in the city. Thus, this study aimed to perform a survey on the occurrence of filarid parasites of household dogs and dogs from animal shelters in the city of Joinville, SC, Brazil.

\section{Material and methods}

This study was carried out in the city of Joinville, located in the northern coast of the state of Santa Catarina $\left(26^{\circ} 18^{\prime} 14^{\prime \prime} \mathrm{S}\right.$ and $\left.48^{\circ} 50^{\prime} 45^{\prime \prime} \mathrm{W}\right)$, in the South of Brazil. It has a total extension of 1,124.10 $\mathrm{km}^{2}$, with $913.7 \mathrm{~km}^{2}$ of a rural area and $210.4 \mathrm{~km}^{2}$ of an urban area ${ }^{(15)}$, bordering the Serra do Mar and Babitonga Bay (Figure 1). The altitude ranges from zero to 1,325 meters and, according to the classification of Köppen and Geiger ${ }^{(19)}$, the regional climate is Cfa, described as humid to super humid, dependent on the Atlantic Polar mass (winter and autumn) and Atlantic Tropical mass (summer and spring) for the season and temperature changes. There is no dry season, and temperatures range from $31{ }^{\circ} \mathrm{C}$ (maximum means) in January to $13{ }^{\circ} \mathrm{C}$ (minimum means) in July, with mean annual relative air humidity of $76.04 \%$.

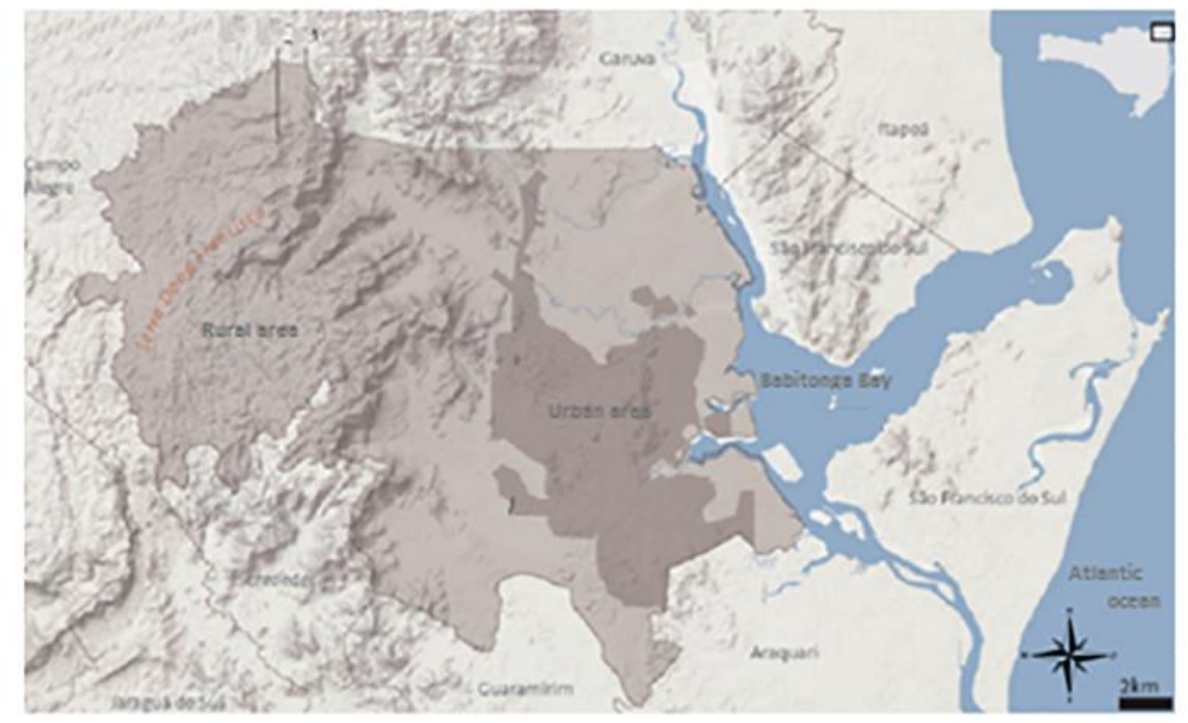

Figure 1. Location map of the municipality of Joinville, SC, Brazil. SOURCE: IPPUJ: Joinville Cidade em Dados, 2016.(20) 
The studies were conducted in three phases from 2015 to 2017, totaling 429 dogs over six months of age, household (considering animals residing in fixed domiciles with responsible guardians) or coming from rescues and temporarily sheltered animal centers of Joinville. None of the dogs participating in the study had a clinical suspicion of heartworm disease.

The first phase of this study was carried out from May to September 2015 using 196 blood samples from household dogs. Samples were collected from dogs treated at veterinary clinics in the city, which had laboratory tests required by clinical veterinarians for various reasons and referred to the clinical laboratory service provider. All the excess material after the tests requested by the clinician were sent to the research laboratory and used in our study.

The second phase comprised the period from October 2015 to October 2016, with 95 blood samples from dogs sheltered by the Animal Shelter of the city of Joinville, identified by sex and animal stall number.

The third phase, carried out between May and December 2017, involved 138 blood samples from dogs domiciled in the city of Joinville, taken by their guardians to veterinary consultations for several reasons. Data on sex and the possible presence of clinical signs indicative of heartworm diseases, such as anorexia, weight loss, apathy, cough, and exercise intolerance, were collected. The study included dogs who have not received heartworm disease preventive drugs within 30 days or microencapsulated moxidectin (ProHeart ${ }^{\circledR}$ SR-12) within one year before sampling collection. The research project was approved by the Ethics Committee of the Federal Institute of Santa Catarina, Araquari Campus, under the number 0177/2016.

The samples were stored under refrigeration in tubes with EDTA and sent to the Laboratory of Veterinary Teaching and Diagnosis - Parasitology of the Federal Institute of Santa Catarina, Araquari Campus, for processing. The whole blood was subjected to the modified Knott technique ${ }^{(21)}$, and the plasma obtained by centrifugation was frozen at $-18{ }^{\circ} \mathrm{C}$. The twenty-four microfilaremic samples found throughout the experiment had larvae measured under an Olympus microscope using the Software Cellsens Standard ${ }^{\circledR}$ program. All samples of the second and third phases, as well as those that presented microfilariae in the first experiment, were submitted to the SNAP 4Dx ${ }^{\circledR}$ Plus clinical diagnostic kit, IDEXX. Additionally, samples from the first and second phases were also evaluated in the thick-drop method ${ }^{(22)}$.

The frequencies of $D$. immitis and $A$. reconditum infection according to sex and origin of dogs (household and sheltered) were compared using the chi-square test, rejecting the null hypothesis at $5 \%$ significance level. The program PAST v. $3.16^{(23)}$ was used. The continuity-correction chi-square test (McNemar's test) was used to compare the sensitivity of microfilariae detection methods.

\section{Results and discussion}

Considering the canine population used in this study $(\mathrm{n}=429), 6.3 \%$ presented parasitism by filarid, $5.6 \%$ positive for $A$. reconditum and $0.7 \%$ for $D$. immitis. In prevalence studies in coastal cities located from $74 \mathrm{~km}$ north of Joinville, Leite et al. ${ }^{(24)}$ found in the city of Guaratuba, PR, and Reifur et al. ${ }^{(9)}$ on the coast of Paraná $0.94 \%$ and $5.47 \%$ of dogs positive for D. immitis, respectively, and $22.6 \%$ positive for A. reconditum. Similarly, in coastal cities located $80 \mathrm{~km}$ south of Joinville, Lira et 
al. ${ }^{(25)}$ verified $4.8 \%$ of dogs parasitized by A. reconditum and none by $D$. immitis in Itajaí, SC, whereas Araújo et al. ${ }^{(26)}$ found $15 \%$ of dogs positive for D. immitis and none for A. reconditum in Florianópolis, SC. Variations of occurrences of filarids in different geographical areas are correlated to the availability of definitive hosts, the possibility of being parasitized by intermediate hosts, and environmental conditions that lead to the multiplication of populations of these hematophagous arthropods. Joinville has environmental conditions that promote the maintenance of multiplication of transmitting mosquitoes. According to Silva and Langoni ${ }^{(27)}$, the frequency of bloodsucking in the canine population is constant in areas where conditions are favorable to the presence of infected mosquitoes throughout the year and may increase the agent transmission rate. In addition, the municipality has the Dona Francisca Environmental Preservation Area, where 112 species of wild mammals, including procyonids and canids as potential hosts of D. immitis, were registered ${ }^{(28)}$. Regarding the transmission of $D$. reconditum, carried out by fleas, parasite dispersion may be influenced by specific conditions of the microenvironment where the dog remains. In our study, sheltered dogs had a higher prevalence of A. reconditum $\left(\mathrm{p}=1.99 \times 10^{-8} ; \chi^{2}=31.50\right)$ in relation to household dogs (Table 1).

Table 1. Dogs parasitized by filarids* in Joinville, SC, as a function of origin and sex

\begin{tabular}{|c|c|c|c|c|c|c|}
\hline \multirow[b]{2}{*}{ Filarid } & \multicolumn{3}{|c|}{ Household } & \multicolumn{3}{|c|}{ Sheltered } \\
\hline & $\begin{array}{c}\text { Male } \\
(n=110)\end{array}$ & $\begin{array}{l}\text { Female } \\
(n=207)\end{array}$ & $\begin{array}{c}\text { Total } \\
(n=317)\end{array}$ & $\begin{array}{c}\text { Male } \\
(n=66)\end{array}$ & $\begin{array}{c}\text { Female } \\
(n=46)\end{array}$ & $\begin{array}{c}\text { Total } \\
(n=112)\end{array}$ \\
\hline A. reconditum & $5(4.5 \%)$ & $1(0.5 \%)$ & $6(1.9 \%)$ & $13(19.7 \%)$ & $5(10.9 \%)$ & $18(16.1 \%)$ \\
\hline D. immitis & $2(1.8 \%)$ & $1(0.5 \%)$ & $3(0.9 \%)$ & 0 & 0 & 0 \\
\hline
\end{tabular}

*Modified Knott method and SNAP 4Dx 2 Plus diagnostic kit.

Significant difference for $A$. reconditum in male and female household dogs $\left(\mathrm{p}=1.99 \times 10^{-8}, \chi^{2}=31.50\right)$ and between the occurrence of $A$. reconditum in household and sheltered dogs $\left(\mathrm{p}=0.01 ; \chi^{2}=6.38\right)$.

Animal confinement in large groups and difficulties in controlling fleas in shelter environments may have contributed to the transmission of $A$. reconditum. Regarding sex, a higher prevalence of $A$. reconditum was observed in males among household dogs $\left(\mathrm{p}=0.01 ; \chi^{2}=6.38\right)$, with no significant difference between sex for sheltered $\operatorname{dogs}\left(\mathrm{p}=0.21 ; \chi^{2}=1.56\right)$. Brito et al. ${ }^{(29)}$ in Brazil and Brianti et al. ${ }^{(11)}$ in Italy also observed no significant differences in the occurrence of this parasite between males and females. However, Hashem and Badawy ${ }^{(30)}$ found a higher prevalence in males. These authors related the susceptibility of these dogs to the infection to possible hormonal effects. In our study, sheltered dogs may not have presented a difference of prevalence according to sex because 68 animals were castrated (70\%), thus preventing the hormonal manifestation of susceptibility. Two of the dogs with $A$. reconditum had clinical signs reported by veterinarians, such as joint pain, lethargy, inappetence, anorexia, weight loss, and cough. Although Hashem and Badawy ${ }^{(30)}$ stated that hemolytic anemia with impaired hepatic and renal function are the main results of $A$. reconditum infection, it is not possible to state that the alterations found in this study have relations with the parasite since the animals could have other diseases concomitant with parasitism.

Microfilariae were found in both used parasitological methods, but the modified Knott method (Newton and Wright, 1956) was more sensitive ( $\left.\mathrm{p}=0.003 ; \chi^{2}=9.09\right)$ (Table 2 ) when compared to the thick-drop method, in addition to allowing the morphological evaluation of microfilariae, favoring species differentiation. According to Dillon et al. ${ }^{(31)}$, the animal must have at least 20 to 50 
microfilariae/mL of blood to be detected by the thick-drop method.

Table 2. Comparison of results obtained by different methods for diagnosis of filarid parasites of dogs from Joinville, SC

\begin{tabular}{lccc}
\hline \multicolumn{1}{c}{ Filarid } & $\begin{array}{c}\text { TD }^{*} \\
(\mathbf{n}=\mathbf{2 9 1})\end{array}$ & $\begin{array}{c}\text { Modified Knott } \\
(\mathbf{n = 4 2 9 )}\end{array}$ & $\frac{\text { SNAP 4Dx }}{(\mathbf{n}=\mathbf{2 4 2})}$ \\
& $8(2.7 \%)$ & $24(5.59 \%)$ & 0 \\
\hline \hline A. reconditum & not evaluated & $2(0.5 \%)$ & $3(1.2 \%)$ \\
\hline . immitis &
\end{tabular}

${ }^{*} \mathrm{TD}=$ Thick-drop method. Samples positive for $D$. immitis were not evaluated using the TD technique.

The $4 \mathrm{Dx}{ }^{\circledR}$ Plus SNAP rapid diagnostic test detects circulating D. immitis antigens and has, on average, $97.5 \%$ sensitivity and $94 \%$ specificity ${ }^{(32)}$. In our study, the three dogs seropositive for D. immitis presented detectable antigens by this diagnostic method, but no microfilariae were found in one of these samples. Occult heartworm disease can occur due to the presence of single-sex parasites, low infection rate ${ }^{(33)}$, microfilaricidal drug-treated animals, and in dogs that have developed an efficient immune response to microfilariae ${ }^{(8)}$. Antigenemia, caused by adult females, usually precedes the appearance of microfilariae in the blood ${ }^{(34)}$. Initially, the three infected dogs detected in this study were evaluated by clinical veterinarians and had no clinical suspicion of heartworm disease, although one had cough and the other apathy, which could be compatible with parasitism. A blood count was requested to assist the diagnosis of the cases, and microfilariae were found at the time of blood smears. Then, these samples were processed by the team of this experiment, when the presence of microfilariae compatible with $D$. immitis and positivity in the antigenic test was confirmed. The third dog was suspected of having ehrlichiosis and had antibodies against Ehrlichia canis or Ehrlichia ewingii and D. immitis when the blood was submitted to SNAP 4Dx ${ }^{\circledR}$ Plus. Subsequently, this sample was processed by our team, confirming the presence of D. immitis antigens and absence of microfilariae in the circulation. The absence of clinical signs can often be observed in parasitized dogs. Larsson et al. ${ }^{(34)}$ found that $42.86 \%$ of dogs infected with $D$. immitis did not present changes in the clinical evaluation. Similarly, Meriem-Hind and Mohamed ${ }^{(35)}$ found that $75.56 \%$ of the dogs were asymptomatic carriers. The absence of signs is related to the number of parasites present, the individual immune response, and the level of exercises to which the dog is submitted ${ }^{(36)}$.

Regarding the morphology of microfilariae, positive samples for A. reconditum had larvae of typical appearance $^{(7)}$, with rounded anterior and presence of "tooth," and some of them with a hooked tail (Figure 2; Table 3). On the other hand, microfilariae of $D$. immitis were larger, with conical anterior portion and straight tails (Figure 3; Table 3).

All positive samples for microfilariae of $A$. reconditum were negative for the presence of $D$. immitis antigens. The mean length of microfilariae of A. reconditum $(269.54 \mu \mathrm{m})$ (Table 3) was similar to that found in dogs from the Northeast of Brazil $(272.3 \pm 4.3 \mu \mathrm{m})^{(7)}$ and Italy $(273.1 \pm 9.4 \mu \mathrm{m})^{(11)}$.

However, when considering the minimum and maximum measurements, we observed $19.8 \%$ of microfilariae of $A$. reconditum out of the limit dimensions of 250-288 $\mu \mathrm{m}$ in length, as limits suggested by Zajac and Conboy ${ }^{(37)}$. Microfilariae of $D$. immitis presented a mean of $321.55 \mu \mathrm{m}$ in length, which is similar to those found by Reifur et al. ${ }^{(9)}(323.49 \pm 12.73 \mu \mathrm{m})$, who studied dogs from the coast adjacent to those of our experiment. However, Ramos et al. ${ }^{(7)}$ found smaller measurements in the state of Pernambuco $(301.2 \pm 7.6 \mu \mathrm{m})$. Among the 65 microfilariae of $D$. immitis measured from the two microfilaremic dogs, 19 (29.23\%) presented length above the limit suggested by Zajac 
and Conboy ${ }^{(37)}$. Reifur et al. ${ }^{(9)}$ found specimens of microfilariae with distinct morphology, not identified by the authors. These data indicate that there are metric and morphological variations among microfilariae found in dogs and should be better studied.
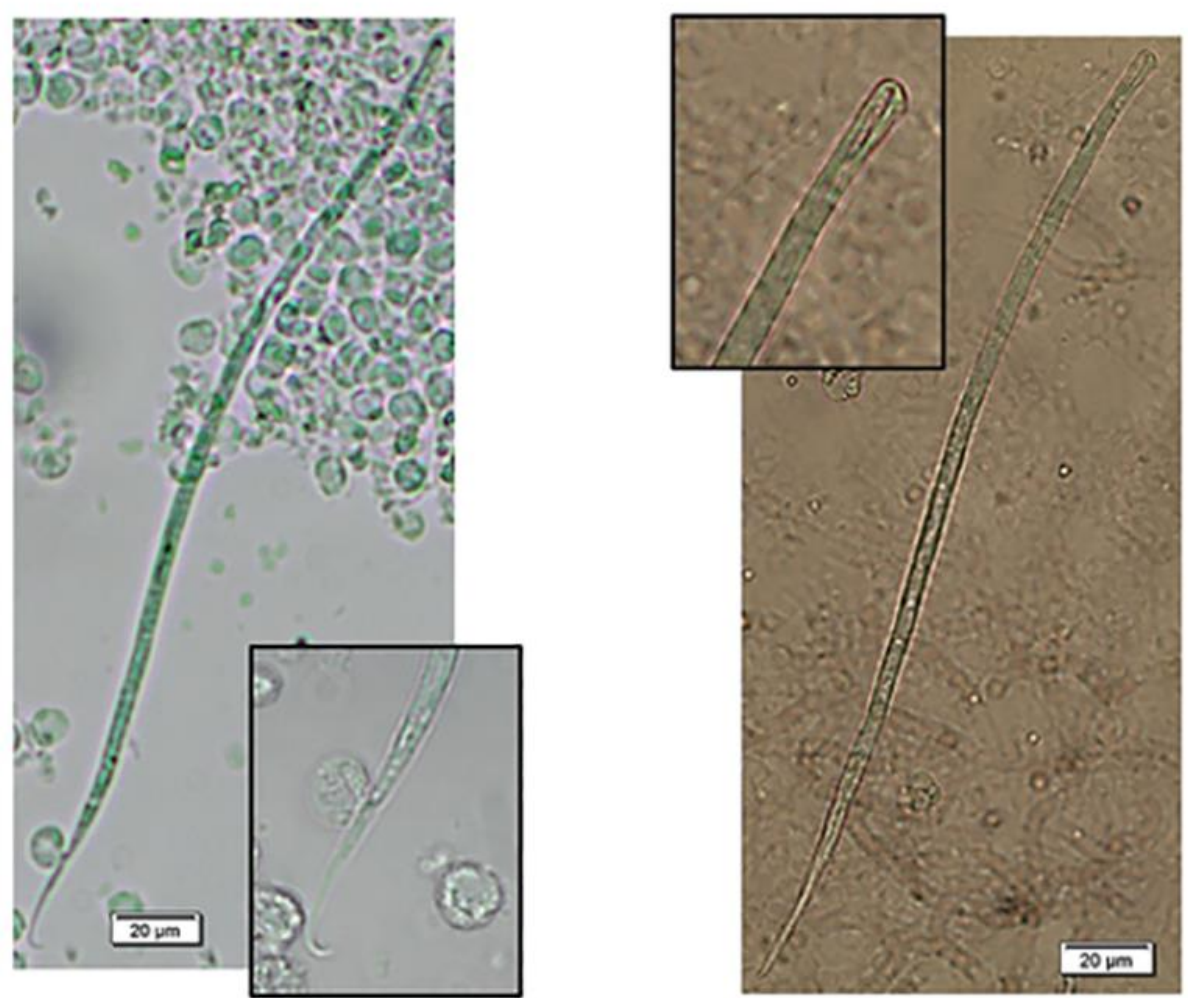

Figure 2. Morphological details of microfilariae of Acanthocheilonema reconditum, with the magnification of the hooked tail and presence of "tooth" in the anterior region.
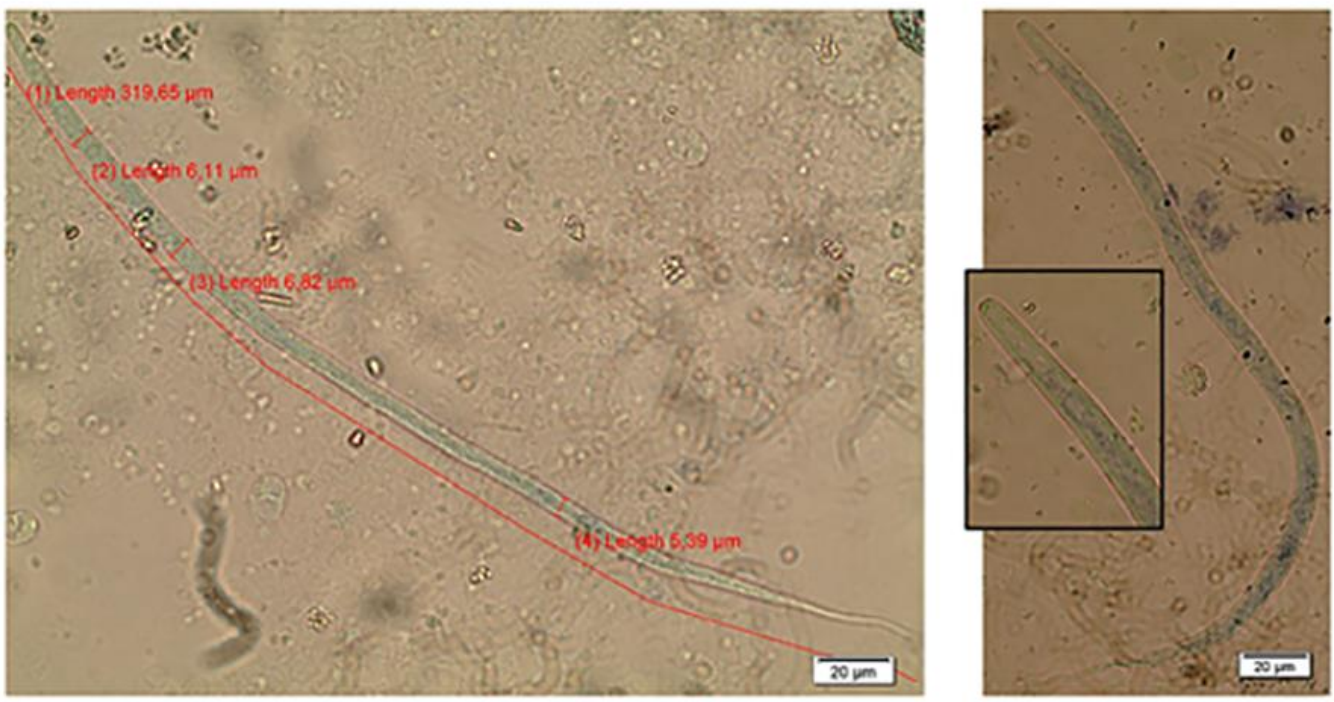

Fonte: Os autores.

Figura 3. Detalhes morfológicos de microfilárias de Dirofilaria immitis, mensuração de comprimento e largura e ampliação da região anterior. 
Table 3. Measurements $(\mu \mathrm{m})$ of microfilariae of Acanthocheilonema reconditum and Dirofilaria immitis in dogs from Joinville, SC

\begin{tabular}{lccc|ccc}
\hline \multicolumn{1}{c}{ Filarid } & \multicolumn{3}{c|}{ Length } & \multicolumn{3}{c}{ Width } \\
& Mean & Minimum & Maximum & Mean & Minimum & Maximum \\
\hline \hline A. reconditum $(\mathrm{n}=96)$ & 269.54 & 233.24 & 296.0 & 4.79 & 3.86 & 5.89 \\
D. immitis $(\mathrm{n}=65)$ & 321.55 & 305.61 & 352.47 & 7.21 & 5.61 & 9.45 \\
\hline
\end{tabular}

Note: it refers to 22 and 2 positive samples for $A$. reconditum and $D$. immitis, respectively.

\section{Conclusions}

This study is the first report of the presence of $D$. immitis in Joinville, SC. The presence of $A$. reconditum and $D$. immitis in native dogs indicates the existence of epidemiological conditions (environment - host - etiological agent) for the transmission and maintenance of these filariae in the region. Considering that $A$. reconditum is an apathogenic parasite and heartworm disease may be a serious disease, the morphological differentiation of microfilariae in the circulation of dogs from the region is essential. The epidemiological information obtained may help the medical and veterinary community regarding the clinical suspicion of canine and human heartworm disease, as well as guide preventive actions targeting public and animal health in the inhabitants of the region.

\section{Acknowledgments}

To Dr. Norma Labarthe and the directors of the Animal Shelter of Joinville. The Research and Innovation Support Foundation of Santa Catarina State (FAPESC) and Federal Institute of Santa Catarina (IFC) funded this project.

\section{References}

1. Moraes MFD; Silva MX; Matos PCM; Albuquerque ACA; Tebaldi JH; Mathias LA; Hope EGL. Filarial nematodes with zoonotic potential in ring-tailed coatis (Nasua nasua Linnaeus, 1766, Carnivora: Procyonidae) and domestic dogs from Iguaçu National Park, Brazil. Veterinary Parasitology: Regional Studies and Reports. 2017;8:1-9. Available at: https://doi.org/10.1016/j.vprsr.2017.01.003.

2. Schacher JF; Sahyoun PF. A chronological study of the histopathology of filarial disease in cats and dogs caused by Brugia pahangi (Buckley and Edeson, 1956). Transactions of the Royal Society of Tropical Medicine and Hygiene, 1967. 61(2):234-236. Available at: https://doi.org/10.1016/0035-9203(67)90162-9

3. Hermosilla C; Pantchev N; Dyachenko V; Gutmann M; Bauer C. First autochthonous case of canine ocular Dirofilaria repens infection in Germany - Short Communication. Veterinary Record, 2006. 158(4):134-135. Available at: http://dx.doi.org/10.1136/vr.158.4.134.

4. Giannetto S; Poglayen G; Gaglio G; Brianti E; Ferlazzo M; Giudice E. Dipetalonema dracunculoides (Nematoda: Onchocercidae): first report in dog in Italy. Parasite, 2003. 10(2):188. 
5. Ravindran R; Varghese S; Nair SN; Balan VM; Lakshmanan B; Ashruf RM; Kumar SS; Gopalan AKK; Nair AS; Malayil A; Chandrasekhar L; Juliet S; Kopparambil D; Ramachandran R; Kunjupillai R; Kakada SAM. Canine Filarial Infections in a Human Brugia malayi Endemic Area of India. Biomed Research International [Internet]. 2014, May; 2014:1-9. Available from: https://www.hindawi.com/journals/bmri/2014/630160/ https://doi.org/10.1155/2014/630160. English.

6. Ionică A.M.; D'Amico G.; Mitková B.; Kalmár Z.; Annoscia G.; Otranto D.; Modrý D.; Mihalca A.D. First report of Cercopithifilaria spp. in dogs from Eastern Europe with an overview of their geographic distribution in Europe. Parasitology Research, 2014. 113(7):2761-2764. Available at: https://doi.org/10.1007/s00436-014$\underline{3931-8 .}$.

7. Ramos RAN; Rêgo AGO; Firmino EDF; Ramos CAN; Carvalho GA; Dantas-Torres F; Otranto D; Alves LC. Filarioids infecting dogs in northeastern Brazil. Veterinary Parasitology, 2016. 226:26-29. Available at: https://doi.org/10.1016/j.vetpar.2016.06.025.

8. Fernandes CGN; Moura ST; Dias AR; Vieira Filho WS. Ocorrência de dirofilariose canina na região da Grande Cuiabá, Estado de Mato Grosso - Brasil. Brazilian Journal of Veterinary Research and Animal Science, 1999. 36(5):258-261. Available at: https://doi.org/10.1590/S1413-95961999000500007.

9. Reifur L; Thomaz-Soccol V; Montiani-Ferreira F. Epidemiological aspects of filariosis in dogs on the coast of Paraná state, Brazil: with emphasis on Dirofilaria immitis. Veterinary Parasitology, 2004. 122(4):273-286. Available at: https://doi.org/10.1016/j.vetpar.2004.05.017.

10. Labarthe NV; Paiva JP; Reifur L; Mendes-de-Almeida F; Merlo A; Pinto CJC; Juliani PS; Almeida MAO; Alves LC. Updated canine infection rates for Dirofilaria immitis in areas of Brazil previoulsy identified as having a high incidence of heartworm-infected dogs. Parasites \& Vectors, 2014. 7:493-500. Available at: https://doi.org/10.1186/s13071-014-0493-7.

11. Brianti E; Gaglio G; Napoli E; Giannetto S; Dantas-Torres F; Bain O; Otranto D. New insights into the ecology and biology of Acanthocheilonema reconditum (Grassi, 1889) causing canine subcutaneous filariasis. Parasitology, 2012. 139(4):530-536. Available at: https://doi.org/10.1017/S0031182011002198.

12. Rani PAMA; Irwin PJ; Gatne M; Coleman GT; Traub RJ. Canine vector-borne diseases in India: a review of the literature and identification of existing knowledge gaps. Parasites \& Vectors, 2010. 3:28. Available at: https://doi.org/10.1186/1756-3305-3-28.

13. Mckay T; Bianco T; Rhodes L; Barnett S. Prevalence of Dirofilaria immitis (Nematoda: Filarioidea) in mosquitoes from Northeast Arkansas, the United States. Journal of Medical Entomology, 2013. 50(4):871878. Available at: https://doi.org/10.1603/ME12197.

14. Labarthe NV; Guerrero J. Epidemiology of heartworm: what is happening in South America and Mexico? Veterinary Parasitology, 2005. 133(2-3):149-156. Available at: https://doi.org/10.1016/j.vetpar.2005.04.006.

15. SEPUD: Joinville Cidade em Dados, 2017. Prefeitura Municipal de Joinville. Joinville. 2017. 73p. (SEPUD - Secretaria de Planejamento Urbano e Desenvolvimento Sustentável).

16. Mello YR; Oliveira TMN. Análise estatística e geoestatística da precipitação média para o município de Joinville (SC). Revista Brasileira de Meteorologia, 2016. 31(2):229-239. Available at: http://dx.doi.org/10.1590/0102-778631220150040.

17. Mello YR; Koehntopp PI. Características climáticas da Bacia Hidrográfica do Rio Cachoeira, Joinville (SC). Acta Biologica Catarinense, 2017. 4(3):18-28. Available at: http://dx.doi.org/10.21726/abc.v4i3.415.

18. Bublitz GS; Serapião MJ; Roberge VD; Coelho KMPA; Serapião CJ. Dirofilariose humana em JoinvilleSC: avaliação clinicopatológica dos primeiros casos relatados na região Sul. Jornal Brasileiro de Patologia e Medicina Laboratorial, 2012. 48(5):383-389. Available at: http://dx.doi.org/10.1590/S1676- 


\section{2}

19. Köppen W; Geiger R. Klimate der Erde. Gotha: Verlag Justus Perthes. 1928. Wall-map 150cmx200cm.

20. IPPUJ: Joinville Cidade em Dados 2016. Prefeitura Municipal de Joinville. Joinville. 2016. 158p. (IPPUJ

- Fundação Instituto de Pesquisa e Planejamento para o Desenvolvimento Sustentável de Joinville).

21. Newton WL; Wright WH. The occurrence of a dog filarid other than Dirofilaria immitis in the U.S.A. Journal of Parasitology, 1956. 42(3):246-258. Available at: https://doi.org/ 10.2307/3274849.

22. Knight DH. Heartworm heart disease. Advances in veterinary science and comparative medicine, 1977. 21:107-149.

23. Hammer Ø; Harper DAT; Ryan PD. PAST: Paleontological Statistics Software Package for Education and Data Analysis. Palaeontologia Electronica [internet]. 2001, May. 4(1):1-9. Available at: http://palaeoelectronica.org/2001_1/past/issue1_01.htm.

24. Leite LC; Navarro-Silva MA; Luz E; Molinari HP; Círio SM; Marinoni LP; Diniz JMF; Leite SC; Lunelli D; Scalet WR. Prevalência de Dirofilaria immitis (Leidy, 1856) em cães do canil municipal de Guaratuba, Paraná, Brasil. Estudos de Biologia, 2007. 29(66):73-79. Available at: http://dx.doi.org/10.7213/reb.v29i66.22209

25. Lira RN; Lempek MR; Neves CC; Souza Junior JC; Poffo GLD. Pesquisa de Dirofilaria immitis e Dipetalonema reconditum no canil municipal de Itajaí, Santa Catarina, Brasil. PUBVET [internet]. 2012. 6(17):1364. Available at: http://www.pubvet.com.br/artigo/2998/pesquisa-de-dirofilaria-immitis-edipetalonema-reconditum-no-canil-municipal-de-itajaiacute-santa-catarina-brasil

26. Araújo RT; Marcondes CB; Bastos LC; Sartor DC. Canine dirofilariasis in the region of Conceição Lagoon, and in the military police kennel, São José, state of Santa Catarina, Brazil. Veterinary Parasitology, 2003. 113(3-4):239-242. Available at: https://doi.org/10.1016/S0304-4017(03)00077-3.

27. Silva RC; Langoni H. Dirofilariose: Zoonose emergente negligenciada. Ciência Rural, 2009. 39(5):16151624. Available at: http://dx.doi.org/10.1590/S0103-84782009005000062.

28. JOINVILLE. Plano de Manejo da Área de Proteção Ambiental Serra Dona Francisca. Joinville: Prefeitura Municipal et al., 2012, 861p.

29. Brito AC; Vila-Nova MC; Rocha DAM; Costa LG; Almeida WAP; Viana LS; Lopes Júnior RR; Fontes G; Rocha EMM; Regis L. Prevalência da filariose canina causada por Dirofilaria immitis e Dipetalonema reconditum em Maceió, Alagoas, Brasil. Cadernos de Saúde Pública, 2001. 17(6):1497-1504. Available at: http://dx.doi.org/10.1590/S0102-311X2001000600021.

30. Hashem MA; Badawy AII. Blood cellular and biochemical studies on filariasis of dogs. Research Journal of Animal Sciences, 2008. 2(5):128-134. Available at: http://medwelljournals.com/abstract/?doi=rjnasci.2008.128.134.

31. Dillon AR; Blagburn BL; Tillson DM; Brawner WR; Spencer J; Welles B; Boothe D. Immature heartworm infection produces pulmonary parenchymal, airway, and vascular disease in cats. Journal of Veterinary Internal Medicine, 2007. 21(3):608-609. Available at: https://doi.org/10.1111/j.19391676.2007.tb03006.x.

32. Henry LG; Brunson KJ; Walden HS; Wenzlow N; Beachboard SE; Barr KL; Long MT. Comparison of six commercial antigen kits for detection of Dirofilaria immitis infections in canines with necropsy-confirmed heartworm status. Veterinary parasitology, 2018. 254:178-182. Available at: https://doi.org/10.1016/j.vetpar.2018.02.037.

33. Larsson MHMA; Iwasaki M; Filho AF; D’errico AA; Ogassawara S; Dutra LF. Contribuição ao 
diagnóstico clínico da dirofilariose canina. Revista da Faculdade de Medicina Veterinária Zootecnia USP, 1987. 24(1):47-59. Available at: https://doi.org/10.11606/issn.2318-3659.v24i1p47-59.

34. Larsson MHMA; Preterote M; Mirandola RMS. Diagnóstico de dirofilariose oculta pelo teste de ELISA em cães do estado de São Paulo. Brazilian Journal of Veterinary Research and Animal Science, 1992. 29(1):9396. Available at: https://doi.org/10.11606/issn.1678-4456.bjvras.1992.51957.

35. Meriem-Hind B; Mohamed M. Prevalence of canine Dirofilaria immitis infection in the city of Algiers, Algeria. African Journal of Agricultural Research [internet]. 2009, Oct. 4(10):1097-1100. Available at: https://academicjournals.org/journal/AJAR/article-abstract/EB2DF7B36067 https://doi.org/10.5897/AJAR. English.

36. Venco L; Kramer L; Genchi C. Heartworm disease in dogs: Unusual clinical cases. Veterinary Parasitology, 2005. 133:207-218. Available at: https://doi:10.1016/j.vetpar.2005.04.010

37. Zajac A.M.; Conboy G.A. Detectionof parasites in the blood. In:Veterinary clinical parasitology. 8th ed. Iowa: Wiley-Blackwell, 2012. p.185-211. English. 